\title{
Subcellular Fractionation of Candida stellatoidea after Growth with Glucose or $\boldsymbol{n}$-Hexadecane
}

\author{
By RICHARD O. JENKINS, ${ }^{1}$ TREVOR G. CARTLEDGE, ${ }^{1 *}$ \\ AND DAVID LLOYD ${ }^{2}$ \\ ${ }^{1}$ Department of Life Sciences, Trent Polytechnic, Nottingham NGI 4BU, U.K. \\ ${ }^{2}$ Department of Microbiology, University College, Newport Road, Cardiff CF1 3NR, U.K.
}

(Received 11 August 1982; revised 22 October 1982)

\begin{abstract}
Spheroplasts of glucose grown and $n$-hexadecane-grown Candida stellatoidea were prepared using snail-enzyme or Zymolyase-5000 and the resultant cell extracts fractionated on sucrose or metrizamide gradients. Organelles from $n$-hexadecane-grown cells were more fragile than those from glucose-grown cells and organelle integrity was maintained only after spheroplast formation using Zymolyase-5000. Isopycnic density gradient centrifugation through metrizamide gradients yielded more complex distributions and markedly higher percentage sedimentabilities of marker enzymes than with sucrose gradients. The zone containing cytochrome $c$ oxidase and all tricarboxylic acid cycle enzymes assayed was readily identified. The density of microbodies appears to be similar to that of mitochondria on either gradient material; on metrizamide a second catalase peak at $\rho=1.07 \mathrm{~g} \mathrm{ml}^{-1}$ was also observed. This zone was shown by electron microscopy to contain organelles up to $1 \mu \mathrm{m}$ diameter, and activities of carnitine acetyltransferase and long chain alcohol and aldehyde dehydrogenases. The first enzyme was located mainly in zones containing mitochondria and microbodies; the last two enzymes were multilocational and of differing distributions, but were found mainly in mitochondrial and microsomal fractions. The possibility that cells grown on $n$-hexadecane contain two populations of microbodies is discussed. Most lysosomes were disrupted on sucrose gradients but sedimented to a density of $1.12 \mathrm{~g} \mathrm{ml}^{-1}$ on metrizamide gradients.
\end{abstract}

\section{INTRODUCTION}

Growth of many yeasts with $n$-alkanes leads to increased development of microbodies and elevated activities of several enzymes (Osumi \& Fukui, 1972; Osumi et al., 1974; Teranishi et al., 1974). In $n$-alkane-grown Candida tropicalis, catalase, D-amino acid oxidase, isocitrate lyase, malate synthase and NADP-linked isocitrate dehydrogenase (Kawamoto et al., 1977) occur in microbody-enriched fractions. Malate dehydrogenase, citrate synthase, aconitase and NAD ${ }^{+}$ linked isocitrate dehydrogenase (Kawamoto et al., 1977), however, were found in mitochondriaenriched fractions. Several other enzymes, namely those of $\beta$-oxidation (Kawamoto et al., 1978a), carnitine acetyltransferase (Kawamoto et al., 1978b) and long chain alcohol and aldehyde dehydrogenases (Yamada et al., 1980) were considered to be distributed between mitochondria and microbodies, and possibly to have yet other locations. Delaissé et al. (1981) studied the distribution of various enzymes from extracts of Candida lipolytica grown on $n$ hexadecane and concluded that a $\omega$-hydroxylase is bound to a membrane that also contains cytochrome P450 and NADPH-cytochrome $c$ oxidoreductase.

All of these studies used either differential or sucrose density gradients in swing-out rotors. Zonal rotors have been used with some success to investigate the subcellular distribution of enzymes from Saccharomyces carlsbergensis (Cartledge \& Lloyd, 1972a, $b$; 1973). In addition, several workers have utilized different gradient materials to fractionate cell extracts from various yeasts, for example Urografin (Matile \& Bahr, 1968), sorbitol (Szabo \& Avers, 1969; 
Neal et al., 1970) and Ficoll (Roggenkamp et al., 1975). In addition, metrizamide has been used successfully to separate lysosomes from mitochondria (Aas, 1973) and peroxisomes from mitochondria (Collot et al., 1976) from rat liver homogenates.

In this paper, we compare the sedimentation of enzymes from spheroplasts of Candida stellatoidea prepared using either snail-enzyme or Zymolyase-5000 and investigate the effect of Triton X-100 on the activities of these enzymes. In addition, the subcellular distributions of several marker enzymes and selected enzymes involved in $n$-hexadecane assimilation are investigated using zonal centrifugation in both sucrose and metrizamide gradients. Enzyme specific activities, recovery data and percentage sedimentabilities are shown after fractionation of extracts of $C$. stellatoidea grown on glucose or $n$-hexadecane.

\section{METHODS}

Maintenance and growth. Candida stellatoidea was maintained on potato dextrose agar slopes. The medium of Veenhuis et al. (1978) was employed for growth, except that yeast extract was added at $0 \cdot 025 \%$. Glucose or $n$ hexadecane was added at $0.8 \%(\mathrm{w} / \mathrm{v})$ and $0.6 \%(\mathrm{v} / \mathrm{v})$, respectively. Cultures $(200 \mathrm{ml})$ were grown in 11 conical flasks at $30^{\circ} \mathrm{C}$ and 200 r.p.m. on a rotary orbital incubator (Gallenkamp). Starter cultures grown to midexponential phase were used as inocula.

Organisms were counted in an Improved Neubauer haemocytometer (Hawksley, Lancing, Surrey, U.K.) after suitable dilution and mixing to separate clumps. Mean generation times in the exponential phase of growth on glucose or $n$-hexadecane were $0.93 \mathrm{~h}$ and $2.63 \mathrm{~h}$, respectively. Cell concentration in stationary phase was $1.0 \times 10^{8}$ cells $\mathrm{ml}^{-1}$ for growth on glucose and $1.8 \times 10^{7}$ cells $\mathrm{ml}^{-1}$ for growth on $n$-hexadecane. Cultures were harvested between $1 \cdot 5$ and $2 \cdot 0 \times 10^{7}$ organisms $\mathrm{ml}^{-1}$ for glucose-grown cells and between $9 \cdot 0$ and $9.8 \times 10^{6}$ organisms ml $^{-1}$ for $n$-hexadecane-grown cells.

Harvesting, preparation and disruption of spheroplasts. All centrifugation procedures were carried out at $4^{\circ} \mathrm{C}$ except during harvesting of glucose-grown cells. A temperature of $4{ }^{\circ} \mathrm{C}$ during harvesting of $n$-hexadecane-grown cells was necessary to remove the residual $n$-hexadecane in solid form.

Organisms were harvested by centrifugation for $2 \mathrm{~min}$ in a $6 \times 250 \mathrm{ml}$ rotor of an MSE 18 centrifuge at $6000 \mathrm{~g}$ for glucose-grown cells or $10000 \mathrm{~g}$ for $n$-hexadecane-grown cells.

Spheroplasts were prepared by one of two methods. (a) The method of Duell et al. (1964) was used except that the snail-enzyme (an extract from the digestive tract of Helix pomatia) was prepared in our laboratory. Incubation was at $30^{\circ} \mathrm{C}$ for $1 \mathrm{~h}\left(\mathrm{pH} \mathrm{4.5)}\right.$. (b) Cells were incubated at $30^{\circ} \mathrm{C}$ for $15 \mathrm{~min}$ in $0.05 \mathrm{M}$-potassium phosphate buffer ( $20 \mathrm{ml}, \mathrm{pH} 7 \cdot 2$ ) containing 0.9 M-sorbitol, 0.1 M-2-mercaptoethanol and 100 units Zymolyase-5000 (Kogyo Co., Tokyo, Japan). Unless otherwise stated, method (b) was employed.

With both methods, greater than $80 \%$ spheroplast formation was accomplished. After washing twice spheroplasts were disrupted in buffer containing $0 \cdot 25 \mathrm{M}$-sucrose, $2 \mathrm{mM}-\mathrm{MgCl}_{2}$ and $10 \mathrm{mM}-\mathrm{Tris} / \mathrm{HCl}(\mathrm{pH} \mathrm{7 \cdot 4)}$. Breakage of spheroplasts was effected by using 15 cycles of a Teflon hand homogenizer, care being taken to avoid cavitation. Whole cells and intact spheroplasts were removed by centrifugation at $600 \mathrm{~g}$ for $5 \mathrm{~min}$. The supernatant, termed the cell extract, was carefully decanted.

Fractionation of cell extract by differential and zonal centrifugation. Differential centrifugation was carried out in an $8 \times 50 \mathrm{ml}$ rotor of an MSE 18 centrifuge at $4{ }^{\circ} \mathrm{C}$. Cell extract was centrifuged at $20000 \mathrm{~g}$ for $20 \mathrm{~min}$ and the supernatant was retained. The pellet was washed once in disruption buffer, supernatants were combined and the volume recorded. The pellet was resuspended in disruption buffer to a known volume.

Zonal centrifugations were carried out in an MSE 50 Superspeed centrifuge. Fractionations through sucrose gradients were performed in a B XIV aluminium rotor by the method described by Cartledge \& Lloyd (1972a). Volume of cell extract was $10 \mathrm{ml}$. Sucrose concentrations were measured using a refractometer. Centrifugation was at $25000 \mathrm{~g}$ for $236 \mathrm{~min}$. Fractionations through metrizamide gradients containing $0.25 \mathrm{M}$-sucrose, $10 \mathrm{~mm}$ Tris $/ \mathrm{HCl}\left(\mathrm{pH} \mathrm{7.4)}\right.$ and $2 \mathrm{mM}-\mathrm{MgCl}_{2}$ were carried out in a $\mathbf{B X X I X}$ aluminium rotor. Metrizamide gradients were constructed in $2.5 \%(\mathrm{w} / \mathrm{v})$ steps, each of $20 \mathrm{ml}$ from 5 to $50 \%(\mathrm{w} / \mathrm{v})$ with $35 \mathrm{ml} 60 \%(\mathrm{w} / \mathrm{v})$ metrizamide as cushion. The overlay contained $30 \mathrm{ml}$ of each of $6 \%$ and $4 \%(\mathrm{w} / \mathrm{v})$ sucrose solutions containing Tris/ $\mathrm{HCl}$ and $\mathrm{MgCl}_{2}$. The volume of cell extract was $10 \mathrm{ml}$. The B XXIX rotor was filled with Tris/ $\mathrm{HCl}(10 \mathrm{~mm}, \mathrm{pH} 7 \cdot 4)$ containing $2 \mathrm{~mm}$ $\mathrm{MgCl}_{2}$. Overlay, cell extract, gradient and cushion were pumped to the outside of the rotor in the order given, at a loading speed of 3000 r.p.m. Centrifugation was carried out at $33000 \mathrm{~g}$ for $180 \mathrm{~min}$. Fractions ( $10 \mathrm{ml})$ were collected from the outside of the rotor after displacement by Tris $/ \mathrm{HCl}$ containing $\mathrm{MgCl}_{2}$ solution. Metrizamide concentrations were measured using a sugar refractometer and converted to density using a calibration curve.

Enzlme assays. The following assays were carried out by previously published methods: aconitase (EC 4.2.1.3) (Fansler \& Lowenstein, 1969); citrate synthase (EC 4.1.3.7) (Srere et al., 1963); malate synthase (EC 4.1.3.2) and isocitrate lyase (EC 4.1.3.1) (Dixon \& Kornberg, 1959); catalase (EC 1.11.1.6) (Lück, 1963). $\mathrm{NAD}^{+}$-linked isocitrate dehydrogenase (EC 1 1 1 1.4) was measured according to Kawamoto et al. (1978a), except 
that the reaction volume was $1 \mathrm{ml}$. Carnitine acetyltransferase was measured according to Kawamoto et al. $(1978 b)$ except that the final reaction volume was $1 \mathrm{ml}$. Malate dehydrogenase (EC 1.1.1.37) was assayed as described by Kitto (1969) except that $0 \cdot 1$ M-potassium phosphate buffer, $\mathrm{pH} 7 \cdot 8$, was used. Cytochrome $c$ oxidase (EC 1.9.3.1) was assayed as described by Smith (1955) except that cytochrome $c$ was previously reduced with dithionite and passed through a G25 Sephadex column. NADPH-cytochrome $c$ oxidoreductase (EC 1.6.2.4) was assayed by the method of Duppel et al. (1973) in the presence of $10 \mu \mathrm{g}$ Antimycin-A. Palmitoyl-CoA dependent reduction of $\mathrm{NAD}^{+}$was measured as described by Mishina et al. (1978). Long chain alcohol dehydrogenase and long chain aldehyde dehydrogenase were measured by the method of Lebeault et al. (1970) with slight modification: the reaction mixture $(1 \mathrm{ml})$ consisted of $44.6 \mathrm{~mm}-\mathrm{Tris} / \mathrm{HCl}$ buffer $(\mathrm{pH} 8.5), 3.3 \mathrm{~mm}-\mathrm{NaN}_{3}, 3.3 \mathrm{~mm}-$ $\mathrm{NAD}^{+}$, extract and $67 \mu 111.94 \mathrm{~mm}$-decanol in acetone (or decanal for aldehyde dehydrogenase). Ethanol dehydrogenase (EC 1.1.1.1) was assayed using the same system but with $67 \mu 16.6$ M-ethanol added instead of decanol. Due to the high UV absorbance of metrizamide, catalase was assayed in metrizamide gradient fractions by the titanium colour reaction for hydrogen peroxide, as described by Fukui et al. (1975), except that $0 \cdot 02 \mathrm{M}$ potassium phosphate buffer, $\mathrm{pH} 7 \cdot 4$, was used. Acid $p$-nitrophenyl phosphatase (EC 3.1.3.2) and alkaline $p$ nitrophenyl phosphatase (EC 3.1.3.1) were assayed by the method of Torriani (1960).

Triton X-100 (final concentration $0.01 \%$ ) was routinely added to enzyme incubation mixtures with the exception of those for catalase, long chain alcohol and aldehyde dehydrogenases and palmitoyl-CoA dependent reduction of $\mathrm{NAD}^{+}$. Acid and alkaline phosphatase assays were carried out in the presence of $0.2 \%$ Triton X-100. All spectrophotometric assays were carried out at $30^{\circ} \mathrm{C}$ using a Pye-Unicam SP1800 spectrophotometer.

Preliminary experiments were carried out with cell extracts to ensure that the enzyme activities were proportional to the amount of extract protein used and were not limited by substrate concentration. Where necessary appropriate dilutions of cell extracts and fractions were used to obtain a suitable enzyme rate.

Protein was measured by the Lowry method with bovine serum albumin as standard. Metrizamide interference in protein determinations was excluded by precipitating the protein in $10 \%(\mathrm{w} / \mathrm{v})$ cold TCA. The protein pellet produced by centrifugation at $10000 \mathrm{~g}$ for $10 \mathrm{~min}$ in the MSE 18 was washed in $10 \%$ cold TCA.

Electron microscopy. Material in fractions was fixed by the addition of $1.5 \mathrm{ml} 24.8 \%(\mathrm{w} / \mathrm{v}$ ) glutaraldehyde (Agar Aids, Bishop's Stortford, Herts, U.K.) to $3 \mathrm{ml}$ of fraction and $2.5 \mathrm{ml}$ disruption buffer. Fixation was for $2 \mathrm{~h}$ at $4{ }^{\circ} \mathrm{C}$ during centrifugation at $17000 \mathrm{~g}$. Post-fixation was with $2 \%$ osmium tetroxide in $0.05 \mathrm{M}$-potassium phosphate buffer ( $\mathrm{pH} 7 \cdot 3)$.

Fixed pellets were stained with $1.5 \%$ uranyl acetate for $90 \mathrm{~min}$, dehydrated through an ethanol series and embedded in Araldite. Sections were cut at a nominal $60 \mathrm{~nm}$ thickness using a Reichert OM U2 ultramicrotome. The sections were stained with saturated uranyl acetate for $15 \mathrm{~min}$ and Reynolds lead citrate for $1.5 \mathrm{~min}$. All specimens were viewed on a AEI 802 electron microscope at $60 \mathrm{kV}$.

Chemicals. All enzyme substrates were obtained from Sigma. Hexadecane was obtained from Aldrich and metrizamide from Nyegaard and Co., Oslo, Norway. All other chemicals were obtained from BDH in AnalaR form.

\section{RESULTS}

Differential centrifugation of cell extracts produced from spheroplasts of cells treated with either snail-enzyme or Zymolyase-5000

Following growth on $n$-hexadecane, approximately 10 times more catalase and malate dehydrogenase and three times more cytochrome $c$ oxidase were sedimented from cell extracts prepared from Zymolyase-5000 than from those prepared using snail-enzyme (Table 1). Extracts of glucose-grown cells showed little difference in the amounts of both catalase and cytochrome $c$ oxidase sedimented irrespective of the methods of extract preparation. Malate dehydrogenase, however, was six times more sedimentable in these extracts following Zymolyase-5000 treatment.

Low sedimentability of enzyme activities for snail-enzyme treated cells suggests loss of enzyme from damaged organelles; consequently Zymolyase- 5000 was employed for further preparations of cell extracts.

\section{Effect of Triton $X-100$ or metrizamide on enzyme activity}

Triton X-100 (final concentration $0.01 \%$ ) increased the activity of a number of enzymes in cell extracts prepared from both glucose and $n$-hexadecane-grown cells (Table 2 ). This effect was probably caused by release of hitherto latent activity from cell organelles. An increase in Triton $\mathrm{X}-100$ final concentration from 0.01 to $0.03 \%$ produced some inhibition of enzyme activity. The 


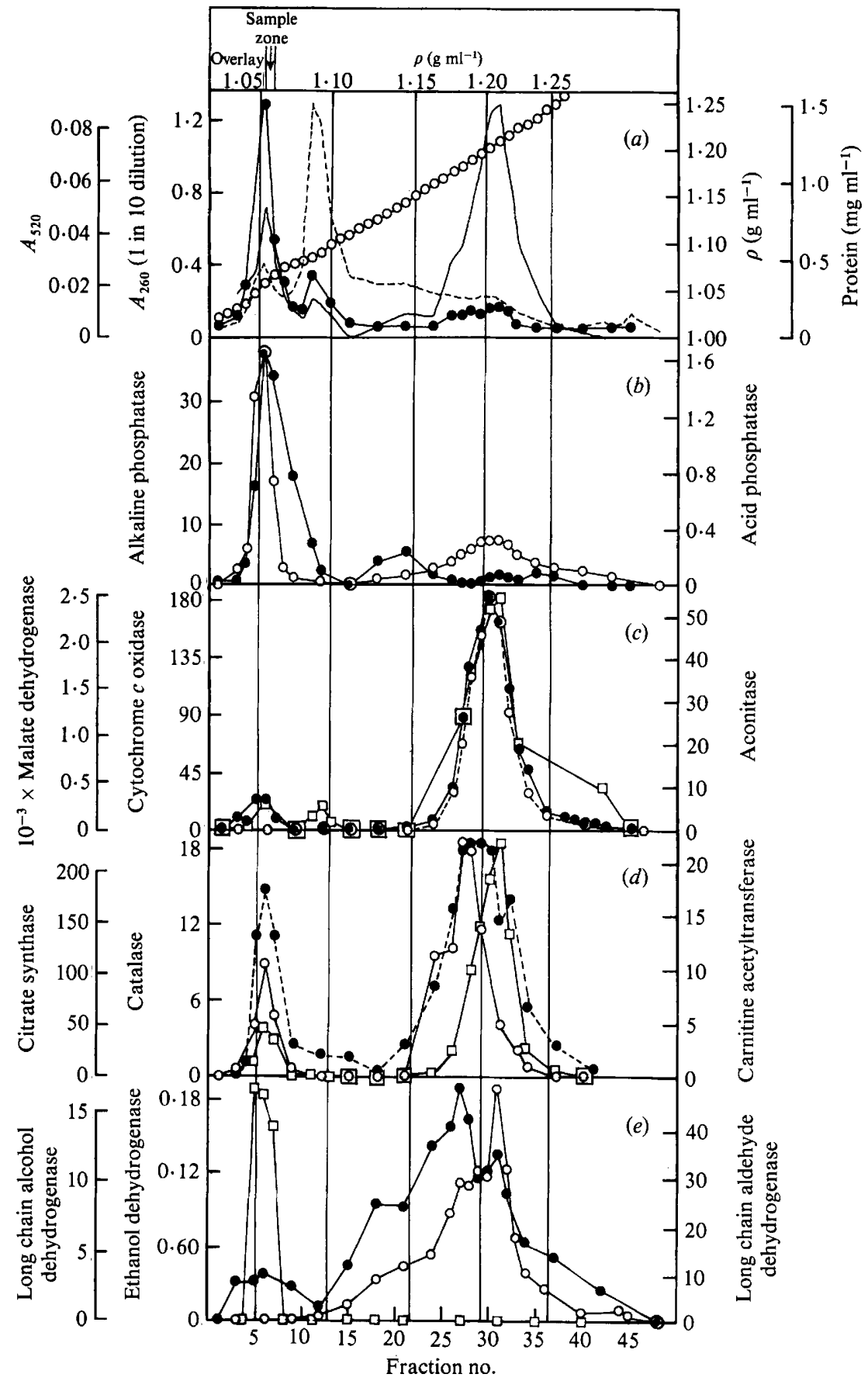

Fig. 1. Zonal centrifugation of a cell extract of glucose-grown C. stellatoidea on a sucrose gradient. Cell extract $(10 \mathrm{ml})$ containing $75 \mathrm{mg}$ protein, was loaded on the gradient. Centrifugation was at 28000 r.p.m. for $236 \mathrm{~min}\left(6 \times 10^{6} \mathrm{~g}\right.$-min at the sample zone; $\left.\int_{0}^{t} \omega^{2} \cdot \mathrm{d} t=1.45 \times 10^{11} \mathrm{rad}^{2} \mathrm{~s}^{-1}\right)$. Enzyme activities shown on the ordinates are milli units $\mathrm{ml}^{-1}$, where one unit represents $\mu \mathrm{mol}$ substrate used or product formed $\mathrm{min}^{-1}$. Where indicated in the text percentage sedimentability refers to the amount of enzyme activity detected beyond $\rho=1 \cdot 10 \mathrm{~g} \mathrm{ml}^{-1}$. (a) Sucrose density gradient (O), light scattering at $520 \mathrm{~nm}(-), 260 \mathrm{~nm}(---)$ and protein $(\bigcirc)$. (b) Alkaline phosphatase $(O)$ and acid phosphatase (๑). (c) Cytochrome $c$ oxidase $(O)$, malate dehydrogenase $(O)$ and aconitase $(\square) .(d)$ Catalase $(O)$, carnitine acetyltransferase $(\bigcirc)$ and citrate synthase $(\square)$. (e) Long chain alcohol dehydrogenase $(O)$, 
Table 1. Sedimentability of selected enzymes in cell extracts prepared by snail-enzyme and Zymolyase-5000 treatment

Sedimentability was calculated as a percentage of the total recovered activity present in the pellet formed following centrifugation at $20000 \mathrm{~g}$ for $20 \mathrm{~min}$. Recoveries of enzyme activity were between 75 and $100 \%$.

$\begin{array}{lccccc}\text { Enzyme } & \overbrace{\begin{array}{c}\text { Snail- } \\ \text { enzyme }\end{array}}^{\text {Zymolyase- }} & & \overbrace{\begin{array}{c}\text { Snail- } \\ \text { enzyme }\end{array}}^{\text {Glucose-grown }} & \begin{array}{c}\text { Zymolyase- } \\ 5000\end{array} \\ \text { Catalase } & 5 & 59 & 73 & 68 \\ \text { Cytochrome } c \text { oxidase } & 31 & 90 & 91 & 96 \\ \text { Malate dehydrogenase } & 7 & 62 & 13 & 84\end{array}$

Table 2. Effect of Triton $X-100$ (final concentration $0.01 \%$ ) on enzyme activity

Enzyme

Increase in activity $(\%)$ in extract

Catalase

Cytochrome $c$ oxidase

Malate dehydrogenase

Aconitase

Carnitine acetyltransferase

$\mathrm{NAD}^{+}$-linked isocitrate dehydrogenase

Isocitrate lyase

NADPH-cytochrome $c$ reductase

$\overbrace{\text { Glucose-grown }}^{\text {Increase in activity }(\%) \text { in ext }} \begin{array}{cr}n \text {-Hexadecan } \\ 19 & 0 \\ 376 & 156 \\ 400 & 212 \\ 669 & 163 \\ 400 & 104 \\ 285 & 78 \\ \text { ND } & 39 \\ 0 & 0\end{array}$

ND, Not detectable.

presence of Triton $\mathrm{X}-100$, even at a final concentration of $0.01 \%$ inhibited the activity of long chain alcohol and aldehyde dehydrogenase and palmitoyl-CoA dependent reduction of $\mathrm{NAD}^{+}$. Rapid freeze-thawing of cell extracts did not alter the activity of the first two enzymes but the activity of the last was lost. Assay mixtures of both acid and alkaline phosphatases employed $0.2 \%$ Triton $\mathrm{X}-100$ to ensure that total (i.e. latent plus free) activities were measured.

Incubation of cell extract in either disruption buffer or disruption buffer containing $30 \%(\mathrm{w} / \mathrm{v})$ metrizamide for $4 \mathrm{~h}$ at $4{ }^{\circ} \mathrm{C}$ showed that metrizamide reduced the detectable activity of a number of enzymes: $\mathrm{NAD}^{+}$-linked isocitrate dehydrogenase activity was reduced by $20 \%$; cytochrome $c$ oxidase, malate dehydrogenase, citrate synthase and palmitoyl-CoA dependent reduction of $\mathrm{NAD}^{+}$by 30 to $40 \%$ and carnitine acetyltransferase activity by more than $40 \%$ and all isocitrate lyase activity was lost. Activities of catalase and NADPH-cytochrome $c$ oxidoreductase were not affected by metrizamide under these conditions. Metrizamide was shown not to affect reagents of the assay systems employed, therefore reductions in activity were caused by direct inhibition or inactivation.

\section{Zonal centrifugation of an extract from glucose-grown cells on a sucrose gradient}

The profiles of absorbance at $260 \mathrm{~nm}$ and $520 \mathrm{~nm}$ showed major peaks at $\rho=1.09 \mathrm{~g} \mathrm{ml}^{-1}$ and $\rho=1.21 \mathrm{~g} \mathrm{ml}^{-1}$, respectively (Fig. $1 a$ ). Approximately $50 \%$ of the protein remained in the sample zone, and relatively small accumulations of protein corresponded with major zones of absorbance at $260 \mathrm{~nm}$ and $520 \mathrm{~nm}$. Acid and alkaline phosphatases were $24 \%$ and $49 \%$ sedimentable, respectively, forming zones of low activity over a broad density range (Fig. $1 \mathrm{~b}$ ).

long chain aldehyde dehydrogenase $(\bullet)$ and ethanol dehydrogenase $(\square)$. Specific activities $[\mathrm{mU}$ (mg protein $)^{-1}$ ] of enzymes in the cell extract were as follows (recoveries in parentheses): protein $(122 \%)$, alkaline phosphatase $27(102 \%)$, acid phosphatase $4(124 \%)$, cytochrome $c$ oxidase $262(51 \%)$, malate dehydrogenase $2291(95 \%)$, aconitase $27(71 \%)$, catalase $19(97 \%)$, carnitine acetyltransferase 30 $(114 \%)$, citrate synthase $29(64 \%)$, long chain alcohol dehydrogenase $11(129 \%)$, long chain aldehyde dehydrogenase $41(142 \%)$ and ethanol dehydrogenase $1(76 \%)$. 


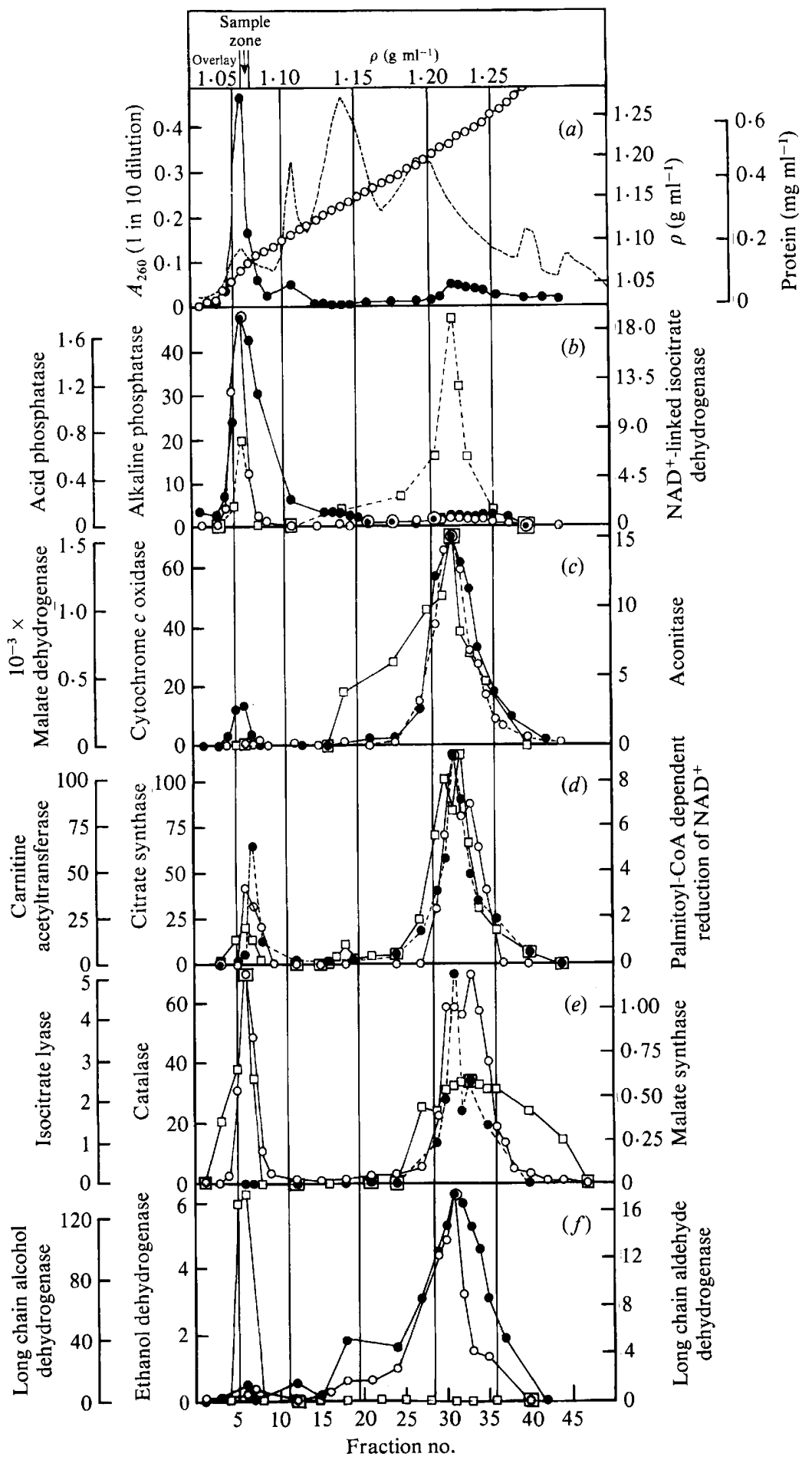

Fig. 2. Zonal centrifugation of a cell extract of $n$-hexadecane-grown $C$. stellatoidea on a sucrose gradient. Cell extract $(10 \mathrm{ml})$ containing $29 \mathrm{mg}$ protein, was loaded on the gradient. Centrifugation was at 28000 r.p.m. for $236 \mathrm{~min}\left(6 \times 10^{6} \mathrm{~g}\right.$-min at the sample zone; $\left.\int_{0}^{t} \omega^{2} . \mathrm{d} t=1.45 \times 10^{11} \mathrm{rad}^{2} \mathrm{~s}^{-1}\right)$. Enzyme activities shown on the ordinates are milli units $\mathrm{ml}^{-1}$, where one unit represents $\mu \mathrm{mol}$ substrate used or product formed $\mathrm{min}^{-1}$. Where indicated in the text percentage sedimentability refers to the 
Non-sedimentable activity was located mainly in the sample zone although acid phosphatase showed evidence of movement into the gradient. All cytochrome $c$ oxidase and $94 \%$ malate dehydrogenase activity gave symmetrical peaks at $\rho=1.20 \mathrm{~g} \mathrm{ml}^{-1}$ (Fig. $1 c$ ). Aconitase (Fig. $1 c$ ) and citrate synthase (Fig. $1 d$ ) sedimented to a higher density of $1.21 \mathrm{~g} \mathrm{ml}^{-1}$, with less than $10 \%$ of their recovered activity remaining in the sample zone. Carnitine acetyltransferase (Fig. $1 \mathrm{~d}$ ) was broadly distributed over a region occupied by catalase, cytochrome $c$ oxidase and citrate synthase. Non-sedimentable activities of carnitine acetyltransferase $(23 \%)$ and catalase $(19 \%)$ remained in or around the sample zone. Particles containing sedimentable catalase (Fig. $1 d$ ) activity were found at a lower density $\left(\rho=1.18 \mathrm{~g} \mathrm{ml}^{-1}\right)$ than those containing cytochrome $c$ oxidase. Over $90 \%$ of the long chain alcohol dehydrogenase and aldehyde dehydrogenase activities (Fig. $1 e$ ) were sedimentable forming broad, complex distributions. The most active fraction for long chain alcohol dehydrogenase was at $\rho=1.21 \mathrm{~g} \mathrm{ml}^{-1}$ corresponding to the peak of citrate synthase activity, whereas the most active fraction for long chain aldehyde dehydrogenase was at $\rho=1.18 \mathrm{~g} \mathrm{ml}^{-1}$ corresponding to the peak of catalase activity. Ethanol dehydrogenase activity (Fig. $1 e$ ) was manifest only in the sample zone.

\section{Zonal centrifugation of an extract from n-hexadecane-grown cells on a sucrose gradient}

The profile of absorbance at $260 \mathrm{~nm}$ was complex showing six distinct maxima (Fig. $2 a$ ). Protein distribution was similar to that for the extract from glucose-grown cells with approximately $50 \%$ remaining in the sample zone (Fig. $2 a$ ). The majority of the acid and alkaline phosphatase activities (Fig. $2 b$ ) were recovered from the sample zone although there was some movement of the former enzyme into the gradient. As shown for the extract from glucose-grown cells, ethanol dehydrogenase was manifest only in the sample zone (Fig. $2 f$ ). With the exception of citrate synthase, catalase and isocitrate lyase, the remaining 12 enzymes showed greater than $80 \%$ sedimentable activity with a maximum at $\rho=1.21 \mathrm{~g} \mathrm{ml}^{-1}$. Maximum activity of citrate synthase (Fig. $2 d ; 94 \%$ sedimentable) was at $\rho=1.23 \mathrm{~g} \mathrm{ml}^{-1}$ and that for catalase (Fig. $2 e ; 73 \%$ sedimentable) was $\rho=1.23 \mathrm{~g} \mathrm{ml}^{-1}$. The most active fraction for isocitrate lyase was in the sample zone and sedimentable activity $(75 \%)$ was distributed over a density range of 1.17 to $1.30 \mathrm{~g} \mathrm{ml}^{-1}$ (Fig. 2e). Cytochrome $c$ oxidase and malate dehydrogenase (Fig. $2 c$ ), palmitoyl-CoA dependent reduction of $\mathrm{NAD}^{+}$(Fig. $2 d$ ), malate synthase (Fig. $2 e$ ) and long chain aldehyde dehydrogenase (Fig. $2 f$ ) all showed either a shoulder or small peak at a higher density than their most active fraction. On the other hand, aconitase (Fig. 2c) and long chain alcohol dehydrogenase (Fig. 2f), together with citrate synthase and catalase, showed either a shoulder or peak of activity at a lower density than their most active fraction.

\section{Zonal centrifugation of an extract from glucose-grown cells on a metrizamide gradient}

Protein showed a complex distribution throughout the gradient (Fig. $3 a$ ). The profile of absorbance at $520 \mathrm{~nm}$ was also complex with three major zones at $\rho=1.05,1.09$ and $1.21 \mathrm{~g} \mathrm{ml}^{-1}$ (Fig. 3a). Distributions of acid and alkaline phosphatases were dissimilar (Fig. 3b). Acid phosphatase activity was located in two major zones at $\rho=1.05$ and $1.11 \mathrm{~g} \mathrm{ml}^{-1}$. Alkaline phosphatase activity, on the other hand, was virtually all non-sedimentable and manifest at a density lower than that of the theoretical sample zone. Cytochrome $c$ oxidase, malate

amount of enzyme activity detected beyond $\rho=1 \cdot 10 \mathrm{~g} \mathrm{ml}^{-1}$. (a) Sucrose density gradient (O), light scattering at $260 \mathrm{~nm}(--)$ and protein $(O) .(b)$ Alkaline phosphatase $(O)$, acid phosphatase $(O)$ and $\mathrm{NAD}^{+}$-linked isocitrate dehydrogenase $(\square) .(c)$ Cytochrome $c$ oxidase $(O)$, malate dehydrogenase $(O)$ and aconitase ( $\square$ ). (d) Palmitoyl-CoA dependent reduction of $\mathrm{NAD}^{+}(\mathrm{O})$, carnitine acetyltransferase $(\odot)$ and citrate synthase $(\square)$. (e) Catalase $(\bigcirc)$, malate synthase $(\odot)$ and isocitrate lyase $(\square)$. ( $f$ ) Long chain alcohol dehydrogenase $(O)$, long chain aldehyde dehydrogenase $(O)$ and ethanol dehydrogenase ( $\square)$. Specific activities [mU (mg protein) $)^{-1}$ ] of enzymes in the cell extract were as follows (recoveries in parentheses): protein $(93 \%)$, alkaline phosphatase $74(118 \%)$, acid phosphatase $7(102 \%)$, NAD ${ }^{+}$-linked isocitrate dehydrogenase $56(77 \%)$, cytochrome $c$ oxidase $257(58 \%)$, malate dehydrogenase $4639(87 \%)$, aconitase $61(78 \%)$, palmitoyl-CoA dependent reduction of $\mathrm{NAD}^{+} 36$ $(50 \%)$, carnitine acetyltransferase $412(63 \%)$, citrate synthase $429(64 \%)$, catalase $315(69 \%)$, malate synthase $39(61 \%)$, isocitrate lyase $25(71 \%)$, long chain alcohol dehydrogenase $416(86 \%)$, long chain aldehyde dehydrogenase $43(155 \%)$ and ethanol dehydrogenase $9(60 \%)$. 


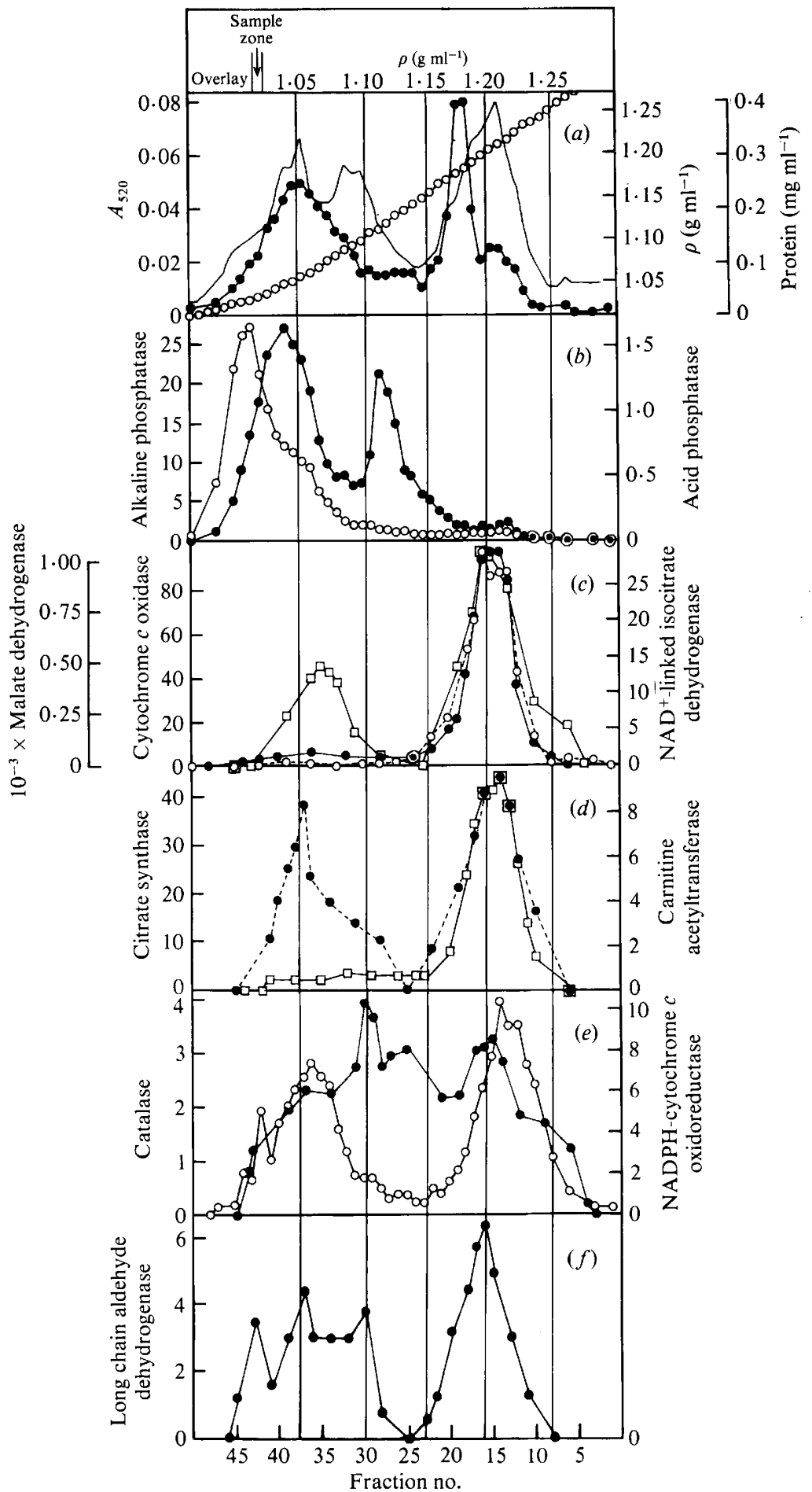

Fig. 3. Zonal centrifugation of a cell extract of glucose-grown C. stellatoidea on a metrizamide gradient. Cell extract $(10 \mathrm{ml})$ containing $56 \mathrm{mg}$ protein, was loaded on the gradient. Centrifugation was at 20000 r.p.m. for $180 \mathrm{~min}\left(6 \times 10^{6} \mathrm{~g}\right.$-min at the sample zone; $\left.\int_{0}^{t} \omega^{2} . \mathrm{d} t=1.45 \times 10^{11} \mathrm{rad}^{2} \mathrm{~s}^{-1}\right)$. Enzyme activities shown on the ordinates are milli units $\mathrm{ml}^{-1}$, where one unit represents $\mu \mathrm{mol}$ substrate used or product formed $\mathrm{min}^{-1}$. Where indicated in the text percentage sedimentability refers to the amount of 
dehydrogenase (Fig. 3c) and citrate synthase (Fig. 3d) formed almost symmetrical peaks of activity at $\rho=1.20$ to $1.22 \mathrm{~g} \mathrm{ml}^{-1}$. A large proportion of $\mathrm{NAD}^{+}$-linked isocitrate dehydrogenase activity (Fig. $3 c$ ) and carnitine acetyltransferase activity (Fig. $3 d$ ) was also located in this region of the gradient. In addition, however, $\mathrm{NAD}^{+}$-linked isocitrate dehydrogenase formed a zone of activity at $\rho=1.07 \mathrm{~g} \mathrm{ml}^{-1}$ and approximately $50 \%$ carnitine acetyltransferase activity was distributed between $\rho=1.03$ and $1.13 \mathrm{~g} \mathrm{ml}^{-1}$. The major portion of catalase activity (Fig. $3 e$ ) sedimented to a region denser than, but overlapping, that of cytochrome $c$ oxidase activity. A second zone of catalase activity corresponded to the peak of carnitine acetyltransferase and $\mathrm{NAD}^{+}$-linked isocitrate dehydrogenase activity at $\rho=1.07 \mathrm{~g} \mathrm{ml}^{-1}$. NADPH-cytochrome $c$ oxidoreductase activity (Fig. $3 e$ ) was distributed throughout the gradient with a maximum at $\rho=1.10 \mathrm{~g} \mathrm{ml}^{-1}$ and a large proportion of activity located in the same region as cytochrome $c$ oxidase activity. For both NADPH-cytochrome $c$ oxidoreductase and $\mathrm{NAD}^{+}$-linked isocitrate dehydrogenase, a pronounced shoulder of activity was evident at a density higher than cytochrome $c$ oxidase activity. Long chain aldehyde dehydrogenase (Fig. $3 f$ ) was recovered from most regions of the gradient with the majority of activity forming a symmetrical peak at $\rho=1.20 \mathrm{~g} \mathrm{ml}^{-1}$. Additional peaks of activity corresponded to the most active fraction of alkaline phosphatase, the most active fraction of NADPH-cytochrome $c$ oxidoreductase and also the peak of carnitine acetyltransferase activity at $\rho=1.05 \mathrm{~g} \mathrm{ml}^{-1}$.

\section{Zonal centrifugation of an extract from $n$-hexadecane-grown cells on a metrizamide gradient}

Protein (Fig. $4 a$ ) was recovered throughout the gradient with relatively large amounts located in fractions containing mitochondrial enzyme activity. Almost all alkaline phosphatase activity was located in a broad band at $\rho=1.04 \mathrm{~g} \mathrm{ml}^{-1}$ (Fig. $4 b$ ). An electron micrograph of this fraction (Fig. $5 a$ ) indicates the presence of ribosomal material and the absence of membraneous organelles. Some acid phosphatase activity (Fig. $4 b$ ) was also recovered from this region, but the major zone of activity had sedimented to $\rho=1 \cdot 12 \mathrm{~g} \mathrm{ml}^{-1}$. Cytochrome $c$ oxidase (Fig. $4 c$ ), citrate synthase (Fig. $4 d$ ) and NAD ${ }^{+}$-linked isocitrate dehydrogenase (Fig. $4 c$ ) formed almost symmetrical peaks of activity at $\rho=1.17 \mathrm{~g} \mathrm{ml}^{-1}$. An electron micrograph of this region (Fig. $5 b$ ) of the gradient demonstrated the presence of mitochondria though these were contaminated with small membraneous vesicles, possibly rough endoplasmic reticulum. The last two enzymes also showed zones of lower activity at lower densities. Although the most active fraction for malate dehydrogenase (Fig. 4c) corresponded to that for cytochrome $c$ oxidase, a substantial amount of activity was found throughout the rest of the gradient. Carnitine acetyltransferase (Fig. $4 d$ ) showed a bimodal distribution with activity manifest in fractions containing cytochrome $c$ oxidase activity, and those containing all recovered activity of palmitoyl-CoA dependent reduction of $\mathrm{NAD}^{+}$at $\rho=1.08 \mathrm{~g} \mathrm{ml}^{-1}$. Catalase activity (Fig. $4 e$ ) was also found in two regions of the gradient; a major zone at $\rho=1.07 \mathrm{~g} \mathrm{ml}^{-1}$ and one at a slightly greater density than that of cytochrome $c$ oxidase activity $\left(\rho=1.19 \mathrm{~g} \mathrm{ml}^{-1}\right)$. Electron micrographs of the region of the gradient at $\rho=1.07 \mathrm{~g} \mathrm{ml}^{-1}$ (Fig. $6 a$ ) reveal the presence of organelles about $1 \mu \mathrm{m}$ in length, whereas the region at $\rho=1.19 \mathrm{~g} \mathrm{ml}^{-1}$ (Fig. 6b) contained what appear to be conventional microbodies with granular matrices and approximately $0.5 \mu \mathrm{m}$ in length. NADPH-cytochrome $c$ oxidoreductase activity (Fig. $4 e$ ) was recovered from most regions of the gradient with peaks of activity in fractions corresponding to those of long chain alcohol dehydrogenase and aldehyde dehydrogenase activity (Fig. $4 f$ ) between $\rho=1.09$ and

enzyme activity detected beyond $\rho=1.10 \mathrm{~g} \mathrm{ml}^{-1}$. (a) Metrizamide density gradient (O), light scattering at $520 \mathrm{~nm}(-)$ and protein $\left({ }^{-}\right)$. (b) Alkaline phosphatase $(O)$ and acid phosphatase $\left(O^{\circ}\right)$. (c) Cytochrome $c$ oxidase $(O)$ malate dehydrogenase $(\bigcirc)$ and $\mathrm{NAD}^{+}-$linked isocitrate dehydrogenase $(\square)$. (d) Carnitine acetyltransferase (O) and citrate synthase $(\square)$. (e) Catalase $(\bigcirc)$ and NADPHcytochrome $c$ oxidoreductase $(O)$. ( $f$ ) Long chain aldehyde dehydrogenase $(O)$. Specific activities [mU ( $\mathrm{mg}$ protein $)^{-1}$ ] of enzymes in the cell extract were as follows (recoveries in parentheses): protein $(114 \%)$, alkaline phosphatase $51(87 \%)$, acid phosphatase $4(102 \%)$, cytochrome $c$ oxidase $380(36 \%)$, malate dehydrogenase $3230(44 \%)$, NAD ${ }^{+}$-linked isocitrate dehydrogenase $122(54 \%)$, carnitine acetyltransferase $64(39 \%)$, citrate synthase $147(49 \%)$, catalase $18(60 \%)$, NADPH-cytochrome $c$ oxidoreductase $43(100 \%)$ and long chain aldehyde dehydrogenase $13(155 \%)$ 


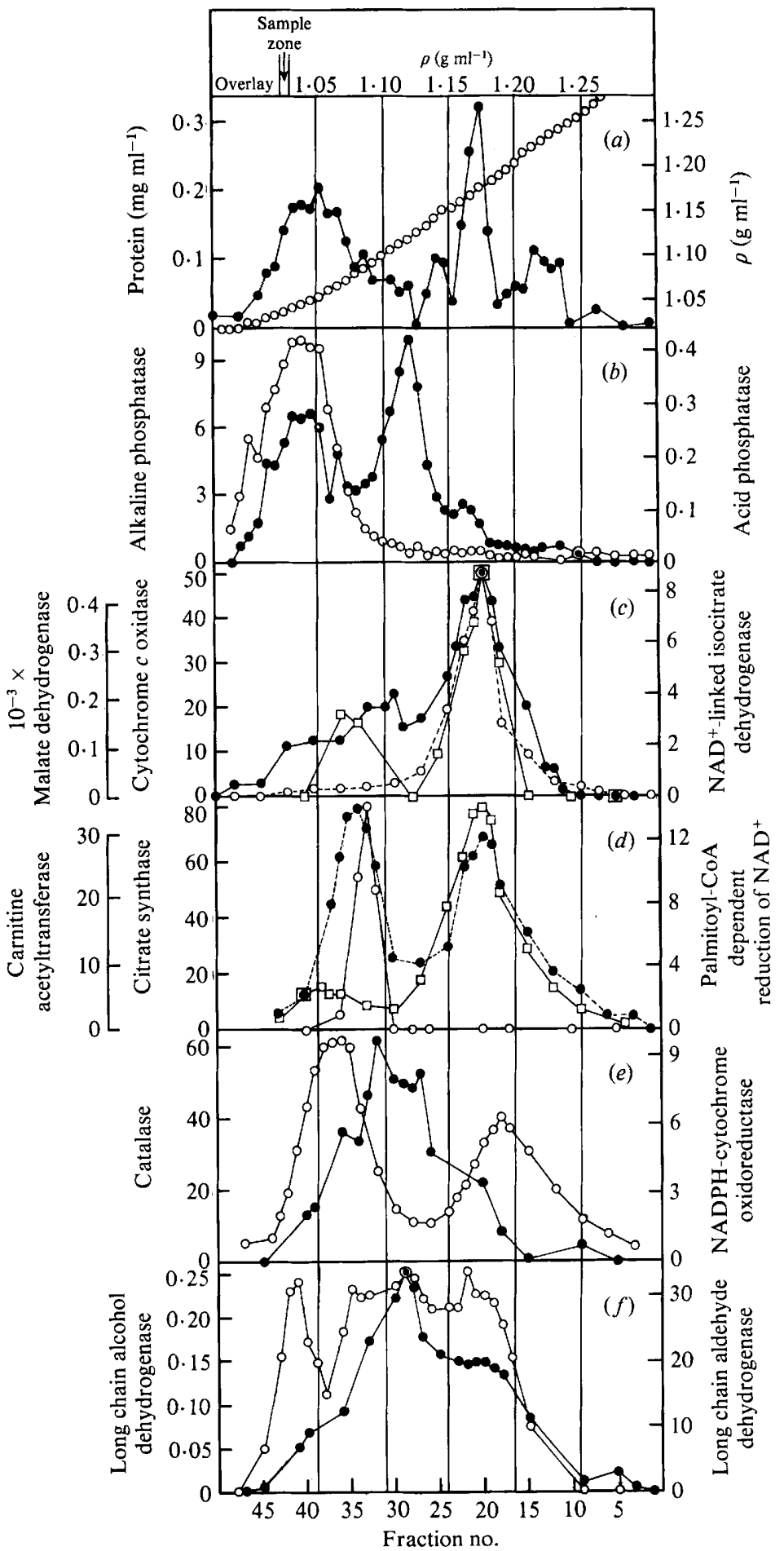

Fig. 4. Zonal centrifugation of a cell extract of $n$-hexadecane-grown $C$. stellatoidea on a metrizamide gradient. Cell extract $(10 \mathrm{ml})$ containing $32 \mathrm{mg}$ protein, was loaded on the gradient. Centrifugation was at 20000 r.p.m. for $180 \mathrm{~min}\left(6 \times 10^{6} \mathrm{~g}\right.$-min at the sample zone; $\left.\int_{0}^{t} \omega^{2} . \mathrm{d} t=1.45 \times 10^{11} \mathrm{rad}^{2} \mathrm{~s}^{-1}\right)$. Enzyme activities shown on the ordinates are milli units $\mathrm{ml}^{-1}$, where one unit represents $\mu \mathrm{mol}$ substrate used or product formed $\mathrm{min}^{-1}$. Where indicated in the text percentage sedimentability refers to the 
$1 \cdot 12 \mathrm{~g} \mathrm{ml}^{-1}$. The distribution of long chain alcohol dehydrogenase was extremely complex showing further major zones of activity in the sample zone and in fractions containing cytochrome $c$ oxidase activity.

\section{DISCUSSION}

Using the criterion of sedimentability to indicate structural integrity of mitochondria and microbodies, there was no gross organelle comminution after snail-enzyme or Zymolyase-5000 treatment of glucose-grown cells, although malate dehydrogenase, an enzyme found largely in the mitochondrial matrix, was partially released after snail-enzyme treatment. For $n$ hexadecane-grown cells, the low sedimentability of the three enzymes shown in Table 1 following snail-enzyme treatment shows that damage is caused to both mitochondria and microbodies and thus Zymolyase-5000 was used in the preparation of spheroplasts.

The results show that care must be taken when incorporating Triton X-100 into enzyme assays. The majority of enzymes exhibit a greater degree of latency in glucose-grown cells than in $n$-hexadecane-grown cells, but are also inhibited by relatively low concentrations of this agent.

Complex distributions of organelles were found throughout the gradients. Mitochondria, as identified by cytochrome $c$ oxidase activity formed symmetrical, sedimentable zones. Structural integrity of mitochondria on sucrose gradients was confirmed by the presence of the activities of established mitochondrial matrix enzymes (malate dehydrogenase, citrate synthase, aconitase and NAD+-linked isocitrate dehydrogenase) within the zone of cytochrome $c$ oxidase activity. The location of some malate dehydrogenase and aconitase activity at regions of lower density, particularly in extracts of $n$-hexadecane-grown cells, may indicate that these mitochondria are more fragile than those from extracts of glucose-grown cells.

For all four fractionations, microbodies (as defined by the major regions of sedimentable catalase activity) were not well separated from the mitochondrial zone. These zones of catalase activity are generally more complex, and of differing densities but are less dense than mitochondria from extracts of glucose-grown cells on sucrose gradients and more dense than mitochondria for the other three conditions. On sucrose gradients, a second peak of activity was evident in the sample zone; more activity in this region from extracts of $n$-hexadecane-grown cells probably indicates increased fragility of microbodies. On metrizamide gradients, there was little activity in the sample zone, though major zones were evident at a density of $1.07 \mathrm{~g} \mathrm{ml}^{-1}$. Electron micrographs indicate the presence of organelles approximately $1 \mu \mathrm{m}$ in length.

Isocitrate lyase and malate synthase were not detectable in extracts of glucose-grown cells. Fractionation in sucrose gradients of extracts of $n$-hexadecane-grown cells indicates that the enzymes are largely sedimentable beyond a density of $1.17 \mathrm{~g} \mathrm{ml}^{-1}$, though with different distributions.

After sucrose gradient fractionations, carnitine acetyltransferase activity was distributed largely between mitochondria and microbodies; a result in agreement with the findings of Kawamoto et al. (1978b). However, in our experiments, the remaining activity was in the sample zone and was not microsomal. After fractionation on metrizamide gradients, carnitine acetyltransferase activity was again located in the mitochondria and microbody region beyond a density of $1.15 \mathrm{~g} \mathrm{ml}^{-1}$ though half of the recovered activity was found associated with the microbodies at a density of $1.07 \mathrm{~g} \mathrm{ml}^{-1}$.

amount of enzyme activity detected beyond $\rho=1 \cdot 10 \mathrm{~g} \mathrm{ml}^{-1}$. (a) Metrizamide density gradient (O) and protein ( ). (b) Alkaline phosphatase $(O)$ and acid phosphatase (O). (c) Cytochrome $c$ oxidase $(O)$, malate dehydrogenase $(\boldsymbol{O})$ and $\mathrm{NAD}^{+}$-linked isocitrate dehydrogenase $(\square)$. (d) Palmitoyl-CoA dependent reduction of $\mathrm{NAD}^{+}(\mathrm{O})$, carnitine acetyltransferase $(\boldsymbol{O})$ and citrate synthase $(\square)$. (e) Catalase $(O)$ and NADPH-cytochrome $c$ oxidoreductase $(O)$. $(f)$ Long chain alcohol dehydrogenase $(\mathrm{O})$ and long chain aldehyde dehydrogenase $(O)$. Specific activities [mU (mg protein $)^{-1}$ ] of enzymes in the cell extract were as follows (recoveries in parentheses): protein $(116 \%$ ), alkaline phosphatase 41 $(84 \%)$, acid phosphatase $3(61 \%)$, cytochrome $c$ oxidase $280(45 \%)$, malate dehydrogenase $4640(45 \%)$, $\mathrm{NAD}^{+}$-linked isocitrate dehydrogenase $63(51 \%)$, palmitoyl-CoA dependent reduction of $\mathrm{NAD}^{+} 37$ $(37 \%)$, carnitine acetyltransferase $239(65 \%)$, citrate synthase $446(57 \%)$, catalase $465(75 \%)$, NADPHcytochrome $c$ oxidoreductase $43(82 \%)$, long chain alcohol dehydrogenase $306(100 \%)$ and long chain aldehyde dehydrogenase $89(103 \%)$. 

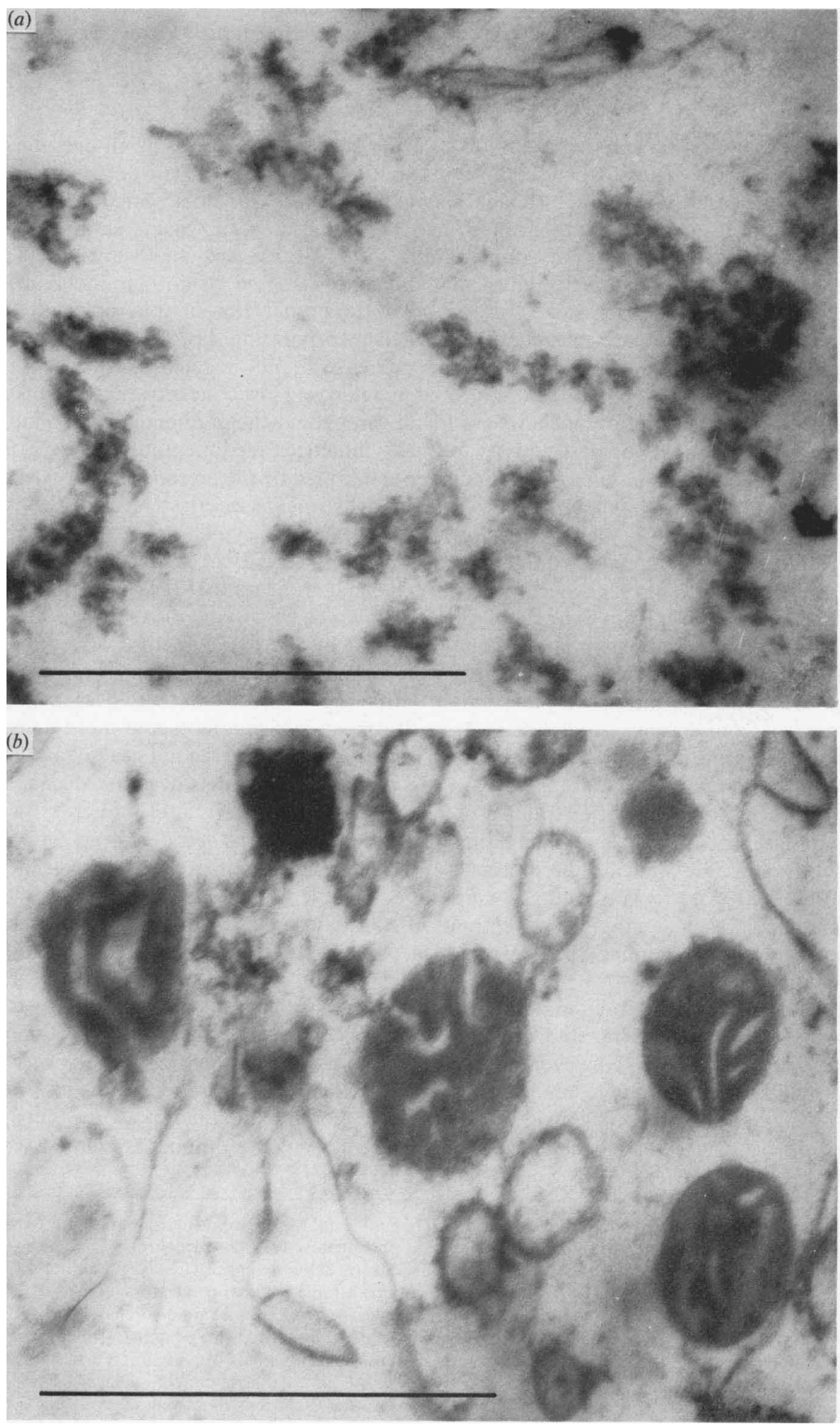

Fig. 5. Electron micrographs of section of material from experiment shown in Fig. 4. (a) Fraction 40, (b) fraction 20. In both cases the bar marker represents $1 \mu \mathrm{m}$. 

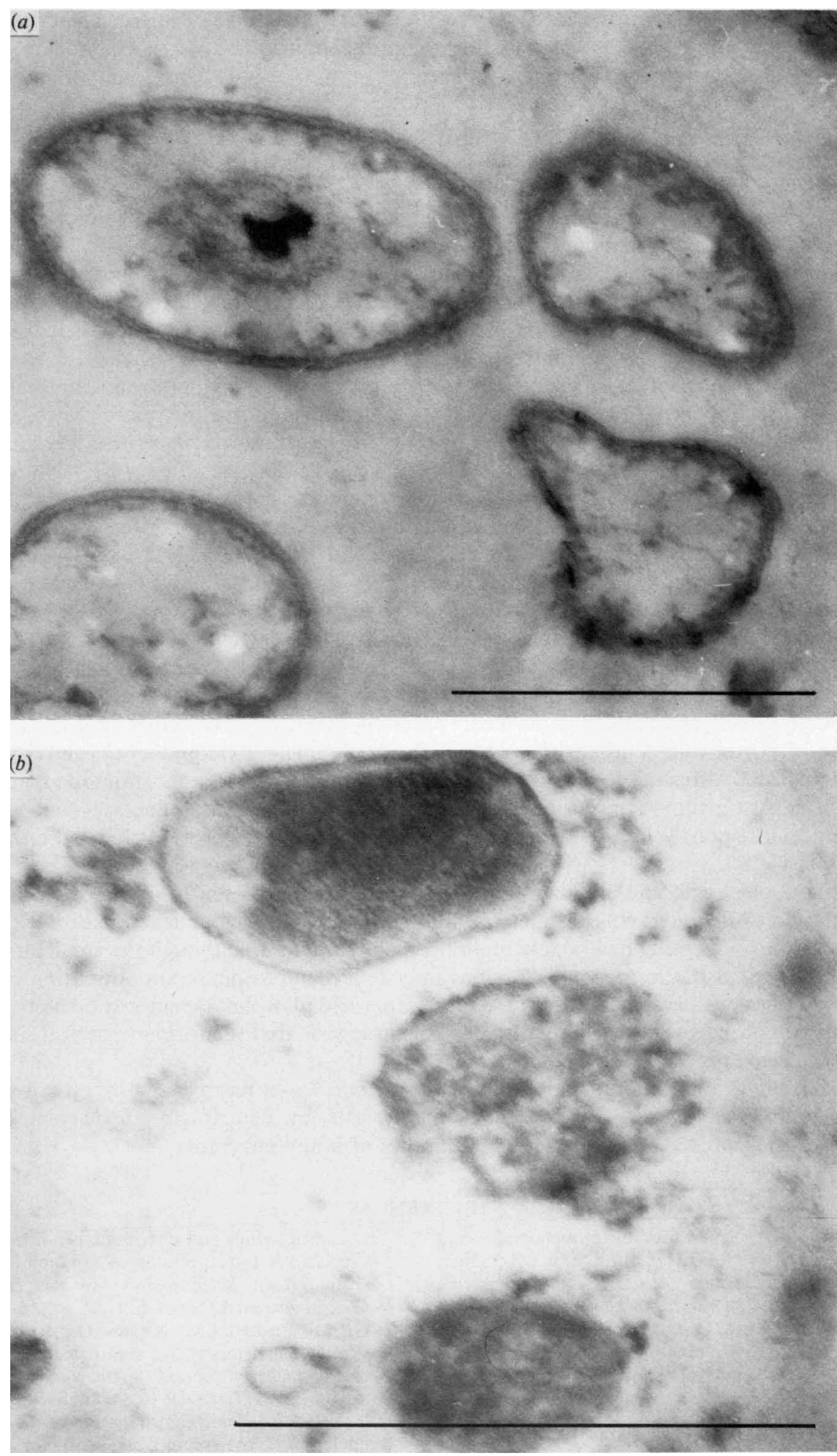

Fig. 6. Electron micrographs of section of material from experiment shown in Fig. 4. (a) Fraction 36, (b) fraction 17. In both cases the bar marker represents $1 \mu \mathrm{m}$. 
After centrifugation of $n$-hexadecane-grown extracts in sucrose gradients, palmitoyl-CoA dependent reduction of $\mathrm{NAD}^{+}$was found in the mitochondria and microbody region, though after centrifugation in metrizamide gradients all of the activity was found in the region containing microbodies at a density of $1.07 \mathrm{~g} \mathrm{ml}^{-1}$.

The term microbody used throughout this paper is a general term including peroxisomes and glyoxysomes. Peroxisomes are recognized as containing catalase and at least one flavin oxidase while the latter contain, in addition, isocitrate lyase and/or malate synthase (Cioni et al., 1981; Tolbert \& Essner, 1981). Our results indicate that whilst only one population of microbodies can be resolved in sucrose gradients, two populations differing in size, density and enzyme complement can be resolved in metrizamide gradients. The possibility that $C$. stellatoidea contains both peroxisomes and glyoxysomes within the same cell must be considered, though it is difficult to confirm this due to the problems in determining the distribution of isocitrate lyase and malate synthase on metrizamide gradients.

After fractionation of extracts on sucrose gradients, long chain alcohol and aldehyde dehydrogenases appeared to be largely associated with mitochondria and microbodies, agreeing with the findings of Yamada et al. (1980) using $C$. tropicalis and $C$. lipolytica. These authors concluded, however, that the enzymes are largely located in microbodies, whereas our results indicated that after growth on $n$-hexadecane long chain alcohol dehydrogenase and probably long chain aldehyde dehydrogenase are mitochondrial. After fractionation on metrizamide gradients of extracts of glucose-grown cells, long chain aldehyde dehydrogenase was again located in the mitochondria, though half of the activity was distributed between the sample zone, microbody zone at $\rho=1.07 \mathrm{~g} \mathrm{ml}^{-1}$ and a zone at $1.10 \mathrm{~g} \mathrm{ml}^{-1}$. The latter zone corresponded to the peak of Antimycin-A insensitive NADPH-cytochrome $c$ oxidoreductase activity which may indicate the presence of microsomal elements. After a similar fractionation on a metrizamide gradient of an extract from $n$-hexadecane-grown cells, the distribution of long chain aldehyde dehydrogenase was markedly different, the majority of activity corresponding to the zone of Antimycin-A insensitive NADPH-cytochrome $c$ oxidoreductase activity. Long chain alcohol dehydrogenase activity was distributed between sample zone, microbody region at $1.07 \mathrm{~g} \mathrm{ml}^{-1}$, Antimycin-A insensitive NADPH-cytochrome $c$ oxidoreductase zone and the mitochondrial region. Where assayed, ethanol dehydrogenase activity was located only in the sample zone.

Distributions of acid and alkaline phosphatase activity are similar to each other on sucrose gradients, but differ markedly on metrizamide gradients. In all four fractionations, alkaline phosphatase activity remained largely in, or near, the sample zone though the small amount of activity located in the mitochondrial zones may reflect microsomal contamination of these organelles. The considerable increase in sedimentable acid phosphatase activity on metrizamide gradients compared with that on sucrose gradients suggests that the former material should be used in experiments to isolate lysosomes.

The subcellular distribution of enzymes in C. stellatoidea is more easily investigated using extracts from Zymolyase- 5000 produced spheroplasts by centrifugation on metrizamide gradients which preserve maximal sedimentability of many enzymes.

\section{REFERENCES}

AAS, M. (1973). Separation of mitochondria and lysosomes from rat liver using a new gradient medium, metrizamide. Abstracts 9th International Congress of Biochemistry, Stockholm, p. 31.

Cartledge, T. G. \& Lloyd, D. (1972a). Subcellular fractionation by differential and zonal centrifugation of aerobically grown-derepressed Saccharomyces carlsbergensis. Biochemical Journal 126, 381393.

Cartledge, T. G. \& Lloyd, D. (1972b). Subcellular fractionation by zonal centrifugation of glucoserepressed anaerobically grown Saccharomyces carlsbergensis. Biochemical Journal 127, 693-703.

Cartledge, T. G. \& Lloyd, D. (1973). Changes in enzyme activities and distributions during glucosederepression and respiratory adaptation of anaerobically grown Saccharomyces carlsbergensis. Biochemical Journal 132, 609-621.

Cioni, M., Pinzauti, G. \& Vanni, P. (1981). Comparative biochemistry of the glyoxylate cycle. Comparative Biochemistry and Physiology 70B, 1-26.

Collot, M., WattiauX-De Connick, S. \& WattiauX, R. (1976). Isopycnic centrifugation of rat liver subcellular particles in sucrose and metrizamide. In Biological Separations in Iodinated Density-Gradient Media, pp. 89-96. Edited by D. Rickwood. London: Information Retrieval Ltd.

Delaissé, J. M., Martin, P., Verheyen-Bouvy, M. F. 
\& NyNs, E. J. (1981). Subcellular distribution of enzymes in the yeast Saccharomycopsis lipolytica grown on $n$-hexadecane, with special reference to $\omega$ hydroxylase. Biochimica et biophysica acta 676, 7790.

Dixon, G. H. \& Kornberg, H. L. (1959). Assay methods for key enzymes of the glyoxylate cycle. Biochemical Journal 72, 3.

Duell, E. A., Inoue, S. \& UTTER, M. F. (1964). Isolation and properties of intact mitochondria from sphaeroplasts of yeasts. Journal of Bacteriology 38, 1762-1768.

Duppel, W., Lebeault, J. M. \& CoON, M. J. (1973). Properties of a yeast cytochrome P-450 containing enzyme system which catalyses the hydroxylation of fatty-acids, alkanes and drugs. European Journal of Biochemistry 36, 583-592.

Fansler, B. \& Lowenstein, J. M. (1969). Aconitase from pig heart. Methods in Enzymology 13, 26-30.

Fukui, S., Tanaka, A., Kawamoto, S., Yasuhara, S., TERANISHI, Y. \& OsUMI, M. (1975). Ultrastructure of methanol-utilizing yeast cells: appearance of microbodies in relation to high catalase activity. Journal of Bacteriology 123, 317-328.

Kawamoto, S., Tanaka, A., Yamamura, M., TeraniSHI, Y. \& FUKUI, S. (1977). Microbody of $n$-alkane grown yeast. Archives of Microbiology 112, 1-8.

Kawamoto, S., Nozaki, C., Tanaka, A. \& Fukui, S. $(1978 a)$. Fatty acid $\beta$-oxidation system in microbodies of $n$-alkane grown Candida tropicalis. European Journal of Biochemistry 83, 609-613.

Kawamoto, S., Ueda, M., Nozaki, C., Yamamura, M., TANAKA, A. \& FUKUI, S. (1978b). Localization of carnitine acetyltransferase in peroxisomes and in mitochondria of $n$-alkane grown Candida tropicalis. FEBS Letters 96, 37-40.

KITTO, G. B. (1969). Intra- and extra-mitochondrial malate dehydrogenase from chicken and tuna heart. Methods in Enzymology 13, 106-116.

Lebeault, J. M., Roche, B., Duvnjak, Z. \& AzouLAY, E. (1970). Alcool et aldéhyde-déshydrogénases particulaires de Candida tropicalis cultivé sur hydrocarbures. Biochimica et biophysica acta 220, 373385.

LÜCK, H. (1963). Catalase. In Methods of Enzymatic Analysis, vol. 2, pp. 885-900. Edited by H. U. Bergmeyer. New York: Academic Press.

MATILE, P. H. \& BAHR, G. F. (1968). Biochemical and quantitative electron microscopical evidence for heterogeneity of mitochondria from Saccharomyces cerevisiae. Experimental Cell Research 52, 301-307.

Mishina, M., Kamiryo, T., Tashiro, S., Hagihara, T., Tanaka, A., Fukui, S., Osumi, M. \& Numa, S. (1978). Subcellular localization of two long chain acyl- coenzyme-A synthetases in Candida lipolytica. European Journal of Biochemistry 89, 321-328.

Neal, W. K., HoffmanN, H. P., Avers, C. J. \& Price, C. A. (1970). Derepression of mitochondria in yeast sphaeroplasts. Biochemical and Biophysical Research Communications 38, 414-422.

Osumi, M. \& Fukui, S. (1972). Relation between the function and the ultrastructure of profusely appearing microbodies in hydrocarbon-utilizing yeasts. 30 th Annual Proceedings of the Electron Microscopy Society of America (Los Angeles), 322-323.

Osumi, M., Miwa, N., Teranishi, Y., Tanaka, A. \& Fukui, S. (1974). Ultrastructure of Candida yeasts grown on $n$-alkanes. Archives of Microbiology 99, 181-201.

Osumi, M., Fukuzumi, F., Teranishi, Y., Tanaka, A. \& FUKUI, S. (1975). Development of microbodies in Candida tropicalis during incubation in a $n$-alkane medium. Archives of Microbiology 103, 1-11.

Roggenkamp, R., SaHM, H., HinkelmanN, W. \& WAGNER, F. (1975). Alcohol oxidase and catalase in peroxisomes of methanol-grown Candida boidinii. European Journal of Biochemistry 59, 231-236.

SMith, L. (1955). Cytochromes $\mathrm{a}, \mathrm{a}_{1}, \mathrm{a}_{2}$, and $\mathrm{a}_{3}$. Methods in Enzymology 2, 736-740.

Srere, P. A., Brazil, H. \& Goren, L. (1963). The citrate condensing enzyme of pigeon breast muscle and moth flight muscle. Acta chemica scandinavica 17, S129-S134.

Szabo, A. \& Avers, C. J. (1969). Some aspects of regulation of peroxisomes and mitochondria in yeast. Annals of the New York Academy of Sciences 168, 302-312.

Teranishi, Y., Tanaka, A., Osumi, M. \& Fukui, S. (1974). Catalase activities of hydrocarbon-utilizing Candida yeasts. Agricultural and Biological Chemistry 38, 1213-1220.

Tolbert, N. E. \& Essner, E. (1981). Microbodies: peroxisomes and glyoxysomes. Journal of Cell Biology 91, 271s-283s.

TORRIANI, A. (1960). Influence of inorganic phosphate in the formation of phosphatases by Escherichia coli. Biochimica et biophysica acta 38, 460-469.

Veenhuis, M., van Dijken, J. P., Pilon, S. A. F. \& HARDER, W. (1978). Development of crystalline peroxisomes in methanol-grown cells of the yeast Hansenula polymorpha and its relation to environmental conditions. Archives of Microbiology 117, 153-161.

Yamada, T., Nawa, H., Kawamoto, S., Tanaka, A. \& FUKuI, S. (1980). Subcellular localization of long chain alcohol dehydrogenase and aldehyde dehydrogenase in n-alkane grown Candida tropicalis. Archives of Microbiology 128, 145-151. 